\title{
GENETIC VARIABILITY STUDIES AMONG OKRA (ABELMOSCHUS ESCULENTUS (L.) MOENCH) VARIETIES GROWN IN SUDAN SAVANNAH AGRO-ECOLOGICAL ZONE OF NIGERIA
}

\author{
HAMISU, A.; A.I. MAGASHI; K.D. DAWAKI; A. ABDULLAHI; \\ N. MUNKAILA; I. DANKANO \\ Department of Crop Production, Kano University of Science and Technology, Wudil PMB 3244, Kano-Nigeria
}

DOI: https://doi.org/10.51193/IJAER.2021.7305

\begin{abstract}
The research was carried out at the teaching and research farm Gaya, Kano University of science and technology Wudil, Kano State and Kiyawa, Jigawa State Nigeria, during 2019/2020 dry season using irrigation to evaluate the genetic variability among some okra varieties grown in Sudan savannah agro-ecological zone of Nigeria. The experiments were laid out in a randomized complete block design (RCBD) with four (4) replications. The treatments consisted of eight Okra varieties (G207, LD88-1, NHAE47-4, Kunchin Biri, Clemson, 'Yar yamidi, G989, and NHBIA13). Data obtained were subjected to analysis of variance (ANOVA) as described by Snedecor and Cochran (1967), and mean were separated by (SNK) at 5\% level of significance using the Statistical Application for the Sciences software (SAS, 2003). Analysis of variance indicated that 9 varieties of okra under study differ significantly for 11 quantitative characters such days to $50 \%$ germination, days to $50 \%$ flowering, days ta first harvest, duration of fruiting, mean pod diameter, mean pod length, number of leaves, number of branches, plant canopy, number of pods per plant, and pod yield per plant in combined analysis across two locations. Taking a simultaneous investigation of the three important genetic parameters together such as genotypic co-efficient of variation, heritability and predicted genetic advance at a glance at phenotypic and genotypic level, characters like days to $50 \%$ germination, days to $50 \%$ flowering, days to first harvest, duration of fruiting, mean pod diameter, mean pod length, number of leaves at harvest and number of pods per plant showed higher values for heritability and genetic advanced.
\end{abstract}

Keywords: Fruit yield, Genetic advance; Heritability, Okra, Variability. 
International Journal of Agriculture and Environmental Research

ISSN: 2455-6939

Volume: 07, Issue: 03 "May-June 2021"

\section{INTRODUCTION}

Okra Abelmoschus esculentus and Hibiscus esculentus (Kumar et al., 2010), and it is commonly called gumbo in Southern USA, lady's finger in England and Kubewa in Northern Nigeria (Ndunguru \& Rajabu 2004). Okra is reported to be an important vegetable crop in Nigeria and is cultivated in both dry and rainy seasons for the green tender pods. In Africa, production is carried during raining season (June - October), irrigation (October - April). It is commonly selffertilized crop but crossing naturally. The breeders and the geneticists have interest in this crop because of the stamens and large flowers and its capsule bears large number of seeds. Two generations can be grown in a year because the duration of the crop is short. Okra is suggested to originate from the Tropical Africa from where it has been distributed to Asia, America, Southern Europe and other countries (Muhammad et al., 2013).FAOSTAT 2016 reported that worldwide production for okra was put at 8.90 million tons grown on 2.15 hectares. As at 2016, the highest okra producing countries include Cote d'Ivoire (112,966 tons), Egypt (55,166 tons), Ghana (66,360 tons), India (5.50 million tons), Iraq (123,583 tons),Malaysia (55,856 tons), Mali (241,033), Nigeria (1.97 million tons), Pakistan (117,961 tons), and Sudan (287,000 tons), [FAOSTAT 2016]. The five best okra producing countries were Iraq, Nigeria, Togo, Sudan and India in 2008 (FAOSTAT, 2010). However, Nigeria ranks third in okra amid fruit vegetables based on production and consumption, succeeding pepper and tomato (Ibeawuchi, 2007). The fruits of Okra are good for soups and stews thickening because of mucilaginous and tender texture nature, (Ijoyah \& Dzer, 2012; Das et al., 2013). The okra pods contents are comprises of $9.7 \%$ carbohydrate, $86.1 \%$ water, $1.0 \%$ fiber, $0.8 \%$ vitamin, $0.2 \%$ fat and $2.2 \%$ protein (Saifullah \& Rabbani, 2009). In addition, the unripe fruits are important sources of vitamin, potassium, calcium, and other minerals. Fruits of Okra are also good in curing ulcers and preventing the pains and effects of haemorrhoids. The mucilage in Okra has medicinal values like plasma replacement or blood volume expander (Siemonsma \& Kouame, 2004). Okra also have beneficial alkaline $\mathrm{pH}$ which assist to ease effect in gastrointestinal ulcer by neutralizing digestive acid (Wamanda, 2007). Paper industries are using mature fruits and stem because it contains more crude fiber. It is also an excellent source of iodine apart from other minerals and vitamins. It is also adaptable to the Nigeria agro ecology and tolerant to various climatic conditions. Substantial morphological degree of variance in the West African okra varieties have been reported by researchers (Adeniji, et al., 2007; Akanbi et al., 2010; Ade Oluwa \& Kehinde, 2011).The knowledge of different varieties determines basis for selection of desirable genotypes for augmentation of yield and other agronomical attributes. Such investigation calculates the feasibility of using available genetic resources for effective improvement. The pods yield in Okra is the most valuable and economic character which is relying on many other attributes. In addition to pods yield, other yield attributing characters like plant height, number of nodes per plant, number of fruits per plant, fruit weight etc. are genetically transmits quantitatively and 
their expression is governed by polygenes which are highly influenced by environment \& lowly heritable. The studies show high genetic variability of important characters among okra varieties. The differences possess in a population is divided and distributed into heritable and non-heritable parameters employ genetically interact components including heritability, the genotypic coefficient of variation and genetic advanced, which are important for selection (Seth et al., 2016).

\section{MATERIELAS AND METHODS}

The experiments were conducted during 2019/2020 dry season at two locations; the Faculty of Agriculture and Agricultural Technology Research Farm Gaya (Farmers Farm); Kano State University of Science and Technology Wudil. Gaya situated at $11.86^{\circ}$ North Latitude, and $9.01^{\circ}$ East and 400 meter elevation above sea level. The mean annual temperature is between $27^{\circ} \mathrm{C}$ to $30.6^{\circ} \mathrm{C}$ and soil type is sandy loam. The second locations were conducted at the Kiyawa local government area, Jigawa State. Kiyawa lies between Latitude 11.41 " $30^{\circ} \mathrm{N}$ and 11.43 " $30^{\circ} \mathrm{E}$. Most part of Jigawa lies within the Sudan savannah with element of Guinea Savannah in the Southern part. The climate of the location is characterized by two seasons: the rainy season (May-September) and the dry season (October-April), and soil type are sandy loam. The experimental materials used were Four improved varieties of okra (LD88-1, NHAE47-4, NHBIA-13 and CLEMSON) sourced from the National Horticultural Research Institute (NIHORT) Bagauda substation, Kano, two inbred lines 207 and G989 were source from Federal University Dutse, while two local variety Kunchin Biri, and 'Yar yamidi were sourced locally from Dutse and Hadejia in Jigawa State, Nigeria.

Table 1: The descriptions of eight okra varieties studied

\begin{tabular}{|l|l|l|}
\hline S/NO & VARIETIES & DESCRIPTIONS \\
\hline 1 & LD88-1 & It has a short stem, small leaves with many flowers and spiny fruits. \\
\hline 2 & NHAE47-4 & This variety has many flowers, big capsules with spinesand dark green fruit. \\
\hline 3 & NHBIA-13 & $\begin{array}{l}\text { The purple leaves are attractive and the pods are ready for harvest in two } \\
\text { months. }\end{array}$ \\
\hline 4 & CLEMSON & Grow to around 4 feet (1.2 meters) tall and mature in about 56 days. \\
\hline 5 & $\begin{array}{l}\text { KUNCHIN } \\
\text { BIRI }\end{array}$ & $\begin{array}{l}\text { It has tall, wine-red stems that match the veining in the leaves, mature in } \\
65 \text { days. }\end{array}$ \\
\hline 6 & $\begin{array}{l}\text { 'YAR } \\
\text { YAMIDI }\end{array}$ & $\begin{array}{l}\text { Okra is equally productive, but one of the more compact kinds of okra and } \\
\text { ready to harvest in 50 days. }\end{array}$ \\
\hline 7 & G207 & $\begin{array}{l}\text { The variety has medium leaves, spiny capsules, short and white stem, mature } \\
\text { in 45-50 days. }\end{array}$ \\
\hline 8 & G989 & \begin{tabular}{l} 
It has a tall stem, small leaves with many flowers and matures in 55-60 days. \\
\hline
\end{tabular}
\end{tabular}


International Journal of Agriculture and Environmental Research

ISSN: 2455-6939

Volume: 07, Issue: 03 "May-June 2021"

The experiments were laid out in a Randomized Complete Block Design (RCBD) with four (4) replications. The two experimental sites were ploughed and harrowed to obtain favourable condition for crop establishment. The entire lands were razed and assemble into seed beds; water channels were also assembled to facilitate good and free water movement and uniform distribution on the plots. The experimental fields were harrow to obtain good tilt and seed beds were made by using small hoes and furrow irrigation to create a favourable condition for plant establishment. The gross field size was $40 \mathrm{~m}$ x $11 \mathrm{~m}\left(440 \mathrm{~m}^{2}\right)$, while the net plot size and the plot size were $2 \mathrm{~m} \times 2 \mathrm{~m}\left(4 \mathrm{~m}^{2}\right)$. A distance of $0.5 \mathrm{~m}$ and $1 \mathrm{~m}$ was left between plots and replication, respectively. The seeds were sown $30 \mathrm{~cm}$ intra and $75 \mathrm{~cm}$ inter row spacing respectively. Two seeds were sown on each spot to acquire adequate germination. The crops were irrigated immediately after planting, and subsequently irrigation was done at 3-4 days interval. The 15:15:15 NPK fertilizer at the rate of $60 \mathrm{~kg}$ N/ha was applied at two split application, three weeks after planting and at flowering stages. Hand hoeing was used to control weeds at 3 and 6 WAS and occasional hand pulling was done to ensure weed free plots and to avoid competition for soil moisture, nutrients, light and gases (oxygen and carbon dioxide). Pods were harvested at every three days interval after first picking. Pods were harvested through hand picking at tender and marketable stage. Data was collected for eleven characters from five centered plants tagged. The eleven characters studied include days to $50 \%$ germination, days to $50 \%$ flowering, days to first harvest, duration of fruiting, plant canopy $(\mathrm{cm})$, number of leaves, number of branches, number of pods per plant, pod length $(\mathrm{cm})$, pod diameter $(\mathrm{cm})$, and pod yield/ plant $(\mathrm{kg} / \mathrm{ha})$. Combined analysis (ANOVA) across the two locations was done with the use of SAS statistical package. However, genotypic variance, phenotypic variance, genotypic coefficient of variation (GCV) and phenotypic coefficient of variation (PCV) were calculated based on the formula reported by Burton (1952). The heritability in broad sense was calculated as proposed by Johnson et al. (1955). The expected genetic advance for each character estimate was established using the procedure of Allard (1960). The estimated genetic advance as percentage of mean was determined by the approach of Comstock \& Robinson (1948), to assess genetic variability of some okra varieties.

\section{RESULTS AND DISCUSSION}

The result revealed significant $(\mathrm{p}<0.05)$ variation among the okra varieties studied for days to $50 \%$ flowering (299.42), days to first harvest (68.82), duration of fruiting (591.07), plant canopy (53.3), mean pod length (31.03), mean pod diameter (7.23), number of leaves (60.66), number of branches (1.35), and number of pods per plant (10.39) in but locations (Table 2), Indicating substantial variability among the varieties for the affected traits. The variation provides sufficient scope for selection of good varieties by the plant breeder for crop advancement or growth. On other hand, non-significant variation in the varieties for days to $50 \%$ germination (1.57) and pod 
International Journal of Agriculture and Environmental Research

ISSN: 2455-6939

Volume: 07, Issue: 03 "May-June 2021"

yield per plant (0.0014) revealed that the varieties were the same for the affected traits. The result also showed variations in the studied varieties for almost all the characters. This variation could be used to select okra characters studied for improvement. Previous researchers supported this result (Düzyaman, 2005; Salesh et al., 2010; Nwangburuka et al., 2012; Hazem et al., 2013; Amoatey et al., 2015). The mean performance for the studied okra varieties indicated a significant variation in days to 50\% flowering (Table 3). The highest number of days to $50 \%$ flowering (61 days) was recorded for Kunchin biri, while the lowest number of days (49 days) was obtained in G207. The average number of days to $50 \%$ flowering was 46.25 days. It indicated that the estimated varieties differed structurally from one another especially on flower producing habits, similar to the findings of Muluken et al. (2016). At the other side, all the okra varieties studied differed in days to first harvest with 'Kunchin biri' being the highest while G207 (41.00 days) variety was the shortest. Plant canopy significantly differed in 'G207' (39.01) possessing the higher plant canopy, whereas Clemson (31.61) was observed the lowest. The numbers of leaves per plant were significantly differed; the highest number was recorded for NHBIA-13 (23.21) whereas the lowest value was observed in Clemson (13.81). The number of branches was significant differed in the variety 'Yar yamidi occupy the highest number (3.76), whereas 'LD88-1' shows the least (2.38). There was a significant difference among the varieties in mean pod length. The highest value was recorded in NHAE47-4 (6.98) variety whereas the lowest value was observed in G207 (12.76) variety. There was a significant difference among the varieties with respect to mean pod diameter. The highest value was recorded in NHAE47-4 (8.88) variety whereas the lowest value was observed in G989 (5.69) variety. There was a significant difference among the varieties with regard to duration in fruiting. The highest value was recorded in Kunchin biri (104.88) variety whereas the lowest value was observed in G207 (77.63) variety. There were significant differences among the varieties with regard to number of pods per plant. The highest rate was recorded in Clemson (11.65) variety whereas the lowest value was observed in NHBIA-13 (8.43). There were significant differences among the varieties with respect to pods yield per plant. The highest value was recorded in 'Yar yamidi (0.23) variety whereas the lowest value was observed in G989 (0.19). The genetic parameters estimates such as genotypic coefficient of variation, phenotypic coefficient of variation, broad sense heritability, and genetic advanced and genetic advance as percentage of mean studied characters are show in Table 4. The small variation with large extent of PCV and GCV between the two genetic parameters revealed the smaller amount of environmental influence on the phenotypic expression. Muluken et al. (2016) earlier buttressed this extrapolation. The studying data in Table 4, discovered that, phenotypic co-efficient of variation (PCV) were higher than genotypic co-efficient of variations (GCV) in all the studied characters. The PCV were highest (48.86) in mean pod length followed by number of leaves at harvest (39.31). The characters like days to $50 \%$ germination (20.18), days to first harvest (11.34), duration of fruiting (20.22), mean pod 
International Journal of Agriculture and Environmental Research

ISSN: 2455-6939

Volume: 07, Issue: 03 "May-June 2021"

length (48.86), number of leaves at harvest (39.31), and number of pods per plant (27.99), shows high values. Other characters, like days to first harvest (11.34) and pod yield per plant (19.04) showed moderate value for this parameter. Many researchers described the consistent variation of okra varieties due to varieties and environmental situations (Thirupathi et al., 2012; AdeOluwa \& Kehinde, 2013; Ehab et al., 2013; Adekoya et al., 2014). The estimate of heritability in broad sense was started from $77.72 \%$ for days to $50 \%$ germination to 99.98 for days to $50 \%$ flowering (Table 4). Reported by Robinson et al. (1955), heritability was classified as low with a range of $0-30 \%$, moderate $(30-60 \%$ ) and higher (above $60 \%$ ). The present investigation shows that, heritability in broad sense of greater than $60 \%$ were recorded in all the characters studied such as days to $50 \%$ germination 77.72 , days to $50 \%$ flowering 99.98 , days to first harvest 97.84, duration of fruiting 99.57, mean pod diameter 87.53, mean pod length 89.63, number of leaves 90.0 , number of branches 95.63 , number of pods per plant 94.95 , plant canopy 91.62 , and pod yield per plant 83.83 ) across locations. When a character is having heritability of $80 \%$ or more, such character would be selected easily. Thus, selection for these characters might arise in in pod yield of okra increment. A very good heritability also indicate good genetic base. (Jagan et al., 2013; Muluken et al., 2016). As reported by Johnson et al. (1955), genetic advance in percent of mean was classified as high (above $20 \%$ ), moderate (10 to $20 \%$ ) and low (0 to 10 $\%$ ). Based on the classification of Johnson et al., days to 50\% flowering (22.52), days to first harvest (48.92), mean pod length (36.40), number of leaves (82.72), number of branches (23.40), number of pods per plant (48.24) and plant canopy (28.36) occupied the genetic advance of greater than $20 \%$ (Table 4). This shows the domination of additive gene effects for these characters. Moderate genetic advance was recorded in Mean pod diameter (16.68), pod yield per plant (17.27) and days to 50\%germination (17.67) respectively. The genetic advance coupled with high estimates of heritability in broad sense gives adequate information on individual character and shows genotypic response to selection (Pradip et al., 2010; Sibsankar et al., 2012). All the characters studied shows high heritability and genetic advance like days to 50\% flowering ( $99.98 \& 22.52$ ), days to first harvest ( $97.84 \& 48.92$ ), mean pod length (89.63 \& $36.40)$, number of leaves (90.0 \& 82.72), number of branches (95.63 \& 23.40), and number of pods per plant (94.95 \& 48.24), plant canopy (91.62 \& 28.36)). (Table4). This finding indicates that variations in the genetic history would endow great change for advancement in selection. Lastly, this shows the bias of additive gene effects for these characters, instead of the environmental influences. Thus, for the improvement of yield selection can be made based on the phenotypic expressions of okra characters (Muluken et al., 2016). 
International Journal of Agriculture and Environmental Research

ISSN: 2455-6939

Volume: 07, Issue: 03 "May-June 2021"

Table 2: Combined mean square values for 11 studied okra character in Gaya and Kiyawa, Nigeria across locations.

\begin{tabular}{|c|c|c|c|c|c|c|c|c|c|c|c|}
\hline $\begin{array}{l}\text { Source } \\
\text { of } \\
\text { variatio } \\
n\end{array}$ & $\begin{array}{l}\text { Days to } \\
50 \% \\
\text { germinat } \\
\text { ion }\end{array}$ & $\begin{array}{l}\text { Days } \\
\text { to } 50 \% \\
\text { flower } \\
\text { ing }\end{array}$ & $\begin{array}{l}\text { Days } \\
\text { to } \\
\text { first } \\
\text { harve } \\
\text { st }\end{array}$ & $\begin{array}{l}\text { Durati } \\
\text { on of } \\
\text { fruitin } \\
\mathrm{g}\end{array}$ & $\begin{array}{l}\text { Mean } \\
\text { pod } \\
\text { diame } \\
\text { ter }\end{array}$ & $\begin{array}{l}\text { Mean } \\
\text { pod } \\
\text { lengt } \\
\mathrm{h}\end{array}$ & $\begin{array}{l}\text { Num } \\
\text { ber of } \\
\text { leave } \\
\mathrm{s}\end{array}$ & $\begin{array}{l}\text { Numb } \\
\text { er of } \\
\text { branc } \\
\text { hes }\end{array}$ & $\begin{array}{l}\text { Num } \\
\text { ber of } \\
\text { pods/ } \\
\text { plant }\end{array}$ & $\begin{array}{l}\text { Plant } \\
\text { cano } \\
\text { py }\end{array}$ & $\begin{array}{l}\text { Pod } \\
\text { yield } \\
\text { / } \\
\text { plant }\end{array}$ \\
\hline $\begin{array}{l}\text { Replicat } \\
\text { ion }\end{array}$ & 0.25 & 18.06 & 3.52 & 21.39 & 2.85 & 6.13 & 38.6 & 0.58 & 2.85 & $\begin{array}{l}77.8 \\
8\end{array}$ & $\begin{array}{l}0.00 \\
39\end{array}$ \\
\hline $\begin{array}{l}\text { Varietie } \\
\mathrm{S}\end{array}$ & $1.57 \mathrm{NS}$ & $\begin{array}{l}299.42 \\
* *\end{array}$ & $\begin{array}{l}68.82 \\
* *\end{array}$ & $\begin{array}{l}591.07 \\
* *\end{array}$ & $\begin{array}{l}7.23 * \\
*\end{array}$ & $\begin{array}{l}31.03 \\
* *\end{array}$ & $\begin{array}{l}60.66 \\
* *\end{array}$ & $\begin{array}{l}1.35 * \\
*\end{array}$ & $\begin{array}{l}10.39 \\
* *\end{array}$ & $\begin{array}{l}53.3 \\
* *\end{array}$ & $\begin{array}{l}0.00 \\
14\end{array}$ \\
\hline Error & 0.45 & 0.06 & 1.52 & 2.54 & 0.33 & 1.65 & 7.02 & 0.15 & 0.95 & 7.59 & $\begin{array}{l}0.00 \\
03\end{array}$ \\
\hline
\end{tabular}

** Highly significant at 5\% level, NS = Non significant difference @ 5\% level.

Table 3: Combined mean performance for 11 characters studied okra across locations in Gaya and Kiyawa, Nigeria.

\begin{tabular}{|c|c|c|c|c|c|c|c|c|c|c|c|}
\hline Variety & DG & $\overline{\mathrm{DF}}$ & DFH & $\mathrm{PC}$ & NOL & NOB & MPL & MPD & DOF & NPP & PYP \\
\hline G207 & $7.63 b$ & $41.00 \mathrm{~g}$ & $49.88 \mathrm{e}$ & 39.01a & $16.44 \mathrm{bc}$ & $2.84 \mathrm{c}$ & 12.76a & $6.00 \mathrm{c}$ & $77.63 \mathrm{e}$ & $10.36 \mathrm{~b}$ & $0.20 \mathrm{c}$ \\
\hline LD88-1 & $7.15 b$ & $49.50 \mathrm{~d}$ & $53.75 \mathrm{c}$ & $36.59 \mathrm{ab}$ & $15.81 b c$ & $\underline{2.38 d}$ & $7.55 \mathrm{de}$ & $7.10 \mathrm{~b}$ & $84.25 \mathrm{~d}$ & $9.30 \mathrm{~cd}$ & $0.21 b c$ \\
\hline NHAE47-4 & $7.00 \mathrm{~b}$ & $50.50 \mathrm{c}$ & $52.38 \mathrm{~d}$ & $34.33 b c$ & $16.66 b c$ & $3.40 \mathrm{ab}$ & $\underline{6,98 \mathrm{e}}$ & 8.88a & $89.63 b$ & $8.43 \mathrm{~d}$ & $0.22 \mathrm{ab}$ \\
\hline $\begin{array}{l}\text { KUNCHIN } \\
\text { BIRI }\end{array}$ & $7.25 b$ & 61.00a & $59.25 a$ & $37.29 a$ & $17.39 \mathrm{~b}$ & $3.21 b c$ & $7.20 \mathrm{e}$ & $7.26 \mathrm{~b}$ & $\underline{104.88 a}$ & $9.96 \mathrm{bc}$ & $0.22 \mathrm{ab}$ \\
\hline $\begin{array}{l}\text { BIRI } \\
\text { CLEMSON }\end{array}$ & $7.13 b$ & $55.00 \mathrm{~b}$ & $55.63 \mathrm{~b}$ & $31.61 \mathrm{c}$ & 13.81c & $2.94 \mathrm{c}$ & $8.80 \mathrm{~cd}$ & $6.93 b$ & $86.88 \mathrm{c}$ & $11.65 a$ & $0.19 \mathrm{c}$ \\
\hline $\begin{array}{l}\text { 'YAR } \\
\text { YAMIDI }\end{array}$ & $7.38 \mathrm{~b}$ & $46.25 \mathrm{e}$ & $53.25 \mathrm{~cd}$ & $31.93 \mathrm{c}$ & $18.58 \mathrm{~b}$ & 3.76a & $7.88 \mathrm{cde}$ & $7.01 \mathrm{~b}$ & $90.25 \mathrm{~b}$ & $8.70 \mathrm{~d}$ & $\underline{0.23 a}$ \\
\hline G989 & $7.63 b$ & $45.50 \mathrm{f}$ & $50.88 \mathrm{e}$ & $34.25 b c$ & $18.51 \mathrm{~b}$ & $2.96 \mathrm{c}$ & $10.56 \mathrm{~b}$ & $\underline{5.69 c}$ & $78.25 \mathrm{e}$ & $8.76 \mathrm{~d}$ & $\underline{0.19 c}$ \\
\hline NHBIA-13 & $\underline{8.38 a}$ & $50.50 \mathrm{c}$ & $52.38 \mathrm{~d}$ & $34.03 b c$ & 23.21a & $3.00 \mathrm{bc}$ & $9.03 c$ & $7.03 \mathrm{~b}$ & $90.13 b$ & $\underline{8.43 d}$ & $0.21 b c$ \\
\hline MEAN & 7.44 & 53.42 & 53.42 & 34.88 & 17.55 & 3.06 & 8.84 & 6.96 & 87.80 & 9.45 & 0.21 \\
\hline $\mathrm{SE} \pm$ & 8.99 & 2.32 & 2.32 & 7.90 & 15.10 & 12.70 & 14.53 & 8.20 & 1.81 & 10.32 & 7.96 \\
\hline
\end{tabular}

Means with the same alphabet(s) are not significantly different at 5\% level of probability by SNK.

$\mathrm{NB}: \mathrm{DG}=$ Days to $50 \%$ germination, $\mathrm{DF}=$ Days to $50 \%$ flowering, $\mathrm{DFH}=$ Days to first harvest, $\mathrm{PC}=$ Plant canopy, NOL $=$ Number of leaves, $\mathrm{NOB}=$ Number of branches, MPL $=$ Mean pod length, $\mathrm{MPD}=$ Mean pod diameter, DOF $=$ Duration of fruiting, NPP $=$ Number of pods per plant, $\mathrm{PYP}=$ Pod yield per plant. 
International Journal of Agriculture and Environmental Research

ISSN: 2455-6939

Volume: 07, Issue: 03 "May-June 2021"

Table 4: Estimates of GCV, PCV, $\mathbf{H}^{2} b, G A$ and GA (\%) mean for eight characters studied across locations in okra in Gaya and Kiyawa, Nigeria.

\begin{tabular}{llllll}
\hline Characters & GCV $(\%)$ & PCV $(\%)$ & $\mathrm{H}^{2} \mathrm{~b}(\%)$ & GA $(\%)$ mean & GA \\
\hline Days to 50\% germination & 16.84 & 19.10 & 77.72 & 17.67 & 1.31 \\
Days to 50\% flowering & 32.39 & 32.40 & 99.98 & 22.52 & 12.03 \\
Days to first harvest & 15.53 & 15.70 & 97.84 & 48.92 & 6.17 \\
Duration of fruiting & 27.69 & 27.75 & 99.57 & 19.39 & 17.02 \\
Mean pod diameter (cm) & 104.89 & 112.12 & 87.53 & 16.68 & 5.81 \\
Mean pod length (cm) & 88.10 & 93.06 & 89.63 & 36.40 & 6.39 \\
Number of leaves at harvest & 18.56 & 6.98 & 90.00 & 82.72 & 1.00 \\
Number of branches at harvest & 87.87 & 89.85 & 95.63 & 23.40 & 2.07 \\
Number of pods per plant & 58.95 & 60.49 & 94.95 & 48.24 & 4.26 \\
Plant canopy at harvest $(\mathrm{cm})$ & 9.24 & 9.65 & 91.62 & 28.36 & 2.68 \\
Pods yield per plant $(\mathrm{g})$ & 17.82 & 19.46 & 83.83 & 17.27 & 0.04 \\
\hline
\end{tabular}

NB: GCV = Genotypic coefficient of variation, $\mathrm{PCV}=$ Phenotypic coefficient of variation, $\mathrm{H}^{2} \mathrm{~B}=$ Heritability in broad sense, GA (\%) mean = Genetic advanced as percentage of mean, GA $=$ Genetic advance

\section{CONCLUSION}

Based on the findings of this research it can be concluded that for the improvement of yield selection can be done through the phenotypic expressions of okra characters and days to first harvest, duration of fruiting, days to $50 \%$ flowering, and number of pods per plant to be considered for further crop advancement in pod yield of okra.

\section{ACKNOWLEDGEMENTS}

The investigators thank the Farm administrator and his entire management theme at the Teaching and Research Farm, faculty of Agriculture and Agricultural technology, Kano University of science and technology Wudil, Kano, Nigeria.

\section{REFERENCES}

Adekoya, M. A., O. J. Ariyo, O. B. Kehinde and A. E. Adegbite. (2014). Correlation and path analyses of seed yield in okra (Abelmoschus esculentus (L.) Moench) grown under different cropping seasons. Pertanika Journal of Tropical Agricultural Sciences, 37(1), $39-49$. 
International Journal of Agriculture and Environmental Research

ISSN: 2455-6939

Volume: 07, Issue: 03 "May-June 2021"

Adeniji, O.T., O. B. Kehinde, M. O. Ajala and M. A. Adebisi. (2007). Genetic studies on seed yield of West African okra (Abelmoschus caillei) (A chev.) Stevels). Journal of Tropical Agriculture, 45(1-2), 36-41.

AdeOluwa, O. O. \& O. B. Kehinde. (2011). Genetic variability studies in West African Okra (Abelmoschus caillei). Agriculture and Biological Journal of North America, 2(10): 1326-1335. doi:10.5251/abjna.2011.2.10.1326-1335

Akanbi, W.B., A. O. Togun, J. A. Adediran and E. A. O. Ilupeju. (2010). Growth, dry matter and fruit yield components of okra under organic and inorganic sources of nutrients. American-Eurasian Journal of Sustainainable Agriculture, 4(1), 1-13.

Akinyele, B. O. \& O. S. Osekita. (2006). Correlation and path coefficient analyses of seed yield attributes in okra (Abelmoschus esculentus (L.) Moench). African Journal of Biotechnology, 5(14), 1330-1336.

Allard, R. W. (1960). Principles of plant breeding. New York: John Willey and Sons. Pp. 485.

Amoatey, H. M., G. Y. P. Klu, E. K. Quartey, H. A. Doku, F. L. Sossah, M. M. Segbefia and J. K. Ahiakpa. (2015). Genetic divergence studies in 29 accessions of okra (Abelmoschus spp (L.) using 13 quantitative traits. American Journal of Experimental Agriculture, 5(3), 217-225. doi:10.9734/AJEA/2015/12306

Burton, G. W. (1952). Quantitative inheritance in grasses. In Proceeding of the 6th Grassland Conference, 7, 227-283.

Comstock, R. E. \& H. F. Robinson (1948). The components of genetic variance in population of bi-parental progenies and their use in estimating the average degree of dominance. Biometrics, 4, 254-266. doi:10.2307/3001412

Das, S, A, Chattopadhyay, S. B. Chattopadhyay, S. Dutta and P. Hazra. (2013). Breeding okra for higher productivity and yellow vein mosaic tolerance. International Journal of Vegetable Science, 19, 58-77. doi:10.1080/19315260.2012.675024

Düzyaman, E. (2005). Phenotypic divergence within a collection of distinct okra (Abelmoschus esculentus) cultivars derived from Turkish land races. Genetic Resources and Crop Evolution, 52(8), 1019-1030. doi:10.1007/s10722-004-6118-9

Ehab, A. A. I., Y. A. Mohamed and M. M. Ali. (2013). Genetic behavior of families selected from some local okra [Abelmoschus esculentus (L.) Moench] populations in Egypt. Plant Breeding and Biotechnology, 1(4), 396 -405. doi:10.9787/PBB.2013.1.4.396 
International Journal of Agriculture and Environmental Research

ISSN: 2455-6939

Volume: 07, Issue: 03 "May-June 2021"

FAOSTAT Data (Food and Agricultural Organisation Statistic); 2016. (Retrieved September 9, 2019)

Hazem, A, S. Obiadalla-Ali, M. H. Z. Eldekashy and A. A. Helaly (2013). Combining ability and heterosis studies for yield and its components in some cultivars of okra [Abelmoschus esculentus (L.) Moench]. American-Eurasian Journal of Agriculture and Environmental Sciences, 13(2), 162-167.

Ibeawuchi, I. K. (2007). Intercropping a food production strategy for resource poor farmers. Nature Science, 5(1), 46-49.

Ijoyah, M. O. \& D. M. Dzer. (2012). Yield Performance of okra ( Abelmoschus esculentus L. Moench) and maize (Zea mays L.) as affected by time of planting maize in Makurdi, Nigeria. Agriculture and Biological Journal of North America, 1(6), 1328332.doi:10.5251/abjna.2010.1.6.1328.1332

Jagan, K. K., K. R. Ravinder, M. Sujatha, V. Sravanthi and V.R. Madhusudhan. (2013). Studies on genetic variability, heritability and genetic advance in okra [Abelmoschus esculentus (L.) Monech]. IOSR Journal of Agriculture and Veterinary Sciences, 5(1), 59-61. doi:10.9790/2380-0515961 Johnson, H. W., H. F.

Robinson and R. E. Comstock. (1955). Estimation of genetic and environmental variability in soybeans. Agronomy Journal, 47, 314-318. doi:10.2134/agronj1955.00021962004700070009x

Kumar, P. S. \& S. Sreeparvathy (2010). Studies on heterosis in okra (Abelmoschus esculentus (L.) Moench). Electronic Journal of Plant Breeding 1(6), 1431-1433.

Muhammad, R. S., A. Muhammad, Z. Khurram, M. J. Muhammad, A. Saeed, I. Qumer and N. Aamir (2013). Growth, yield and seed production of okra as influenced by different growth regulators. Pakistan Journal of Agricultural Science, 50(3), 387-392.

Muluken, D., M. Wassu and G. Endale (2016). Variability, heritability and genetic advance in Ethiopian okra [Abelmoschus esculentus (L.) Monech] collections for tender fruit yield and other agro-morphological traits. Journal of Applied Life Sciences International, 4(1), 1-12. doi:10.9734/JALSI/2016/19483

Ndunguru J, Rajabu AC (2004): Effect of okra mosaic virus disease on the above-ground morphological yield components of okra in Tanzania. Scientia Horticulturae 99: 225-235 
International Journal of Agriculture and Environmental Research

ISSN: 2455-6939

Volume: 07, Issue: 03 "May-June 2021"

Nwangburuka, C.C., O. A. Denton, O. B. Kehinde, D. K. Ojo and A. R. Popoola. (2012). Genetic variability and heritability in cultivated okra [Abelmoschus esculentus (L.) Moench]. Spanish Journal of Agricultural Research, 10(1), 123-129. doi:10.5424/sjar/2012101021-11

Saifullah M \& M. G. Rabbani (2009). Evaluation and characterization of Okra (Abelmoschus esculentus L. Moench.) cultivars. SAARC Journal of Agriculture, 7(1), 92-99.

Salesh K. J., A. Deepak and T. R. Ghai (2010). Variability studies for yield and its contributing traits in okra. Electronic Journal of Plant Breeding, 1(6), 1495-1499.

SAS (2011). Statistical analysis system (SAS) software for windows version 9.2. Vol.1, SAS Institute. Cary, N.C. USA.

Seth, T., A. Chattopadhyay, S. Chatterjee, S. Dutta and B. Singh (2016). Selecting parental lines among cultivated and wild species of okra for hybridization aiming at YVMV disease resistance. Journal of Agricultural Science and Technology. 18, 751-762.

Sibsankar, D., C. Arup, B. C. Sankhendu, D. Subrata and H. Pranab (2012). Genetic parameters and path analysis of yield and its components in okra at different sowing dates in the Gangetic plains of eastern India. African Journal of Biotechnology, 11(95), 1613216141. doi:10.5897/AJB12.545

Siemonsma JS, Kouame C, (2004). Vegetables. In: Plant Resources of Tropical Africa 2 (Grubben GJH and Denton OA, Eds.). PROTA Foundation, Wageningen, Netherlands/Backhuys Publ, Leinden, Netherlands/CTA, Wageningen, Netherlands. Pp: 21-29.

Tavakoli, N., Dehkordi, G.N., Teimouri, R., Hamishehkar, H. (2008). Characterization and evaluation of Okra gum as a tablet binder. Jundishapur Journal of Natural Pharmaceutics Products 3(1): 33 - 38.

Thirupathi, R. M., B. K. Hari, M. Ganesh, R. K. Chandrasekhar, H. Begum, R. B. Purushothama and G. Narshimulu. 2012. Genetic variability analysis for the selection of elite cultivars based on pod yield and quality from the germplasm of okra [Abelmoschus esculentus (L.) Moench]. Journal of Agricultural Technology, 8, 639-655.

Pradip, K., D. K. Akotkar and A. K. De Pal. (2010). Genetic variability and divergence in okra [ Abelmoschus esculentus (L).Moench]. Electronic Journal of Plant Breeding, 1(4), 393398. 
International Journal of Agriculture and Environmental Research

ISSN: $2455-6939$

Volume: 07, Issue: 03 "May-June 2021"

Wamanda, D.T (2007). Inheritance studies in collected local Okra (Abelmoschus esculentus L. Moench) cultivars. In: Combining ability analysis and heterosis on diallel cross of okra. African Journal of Agricultural Research. 5(16), 2108-2155. 